\title{
The Permo-Carboniferous Oslo Rift through six stages and 65 million years
}

1 Det Norske Oljeselskp ASA, Norway.E-mail: bjorn.tore.larsen@detnor.no

2 Eni Norge AS. E-mail: snorre.olaussen@eniniorge.com

3 NHM, UiO.E-mail: b.a.sundvoll@nhm.uio.no

4 Inst. for Geofag, UiO.E-mail: michael.heeremans@geo.uio.no

The Oslo Rift is the northernmost part of the Rotliegendes basin system in Europe. The rift was formed by lithospheric stretching north of the Tornquist fault system and is related tectonically and in time to the last phase of the Variscan orogeny. The main graben forming period in the Oslo Region began in Late Carboniferous, culminating some 20-30 Ma later with extensive volcanism and rifting, and later with uplift and emplacement of major batholiths. It ended with a final termination of intrusions in the Early Triassic, some 65 Ma after the tectonic and magmatic onset.

We divide the geological development of the rift into six stages. Sediments, even with marine incursions occur exclusively during the forerunner to rifting. The magmatic products in the Oslo Rift vary in composition and are unevenly distributed through the six stages along the length of the structure.

\section{Introduction}

The Oslo Palaeorift (Figure 1) contributed to the onset of a prolonged period of extensional faulting and volcanism in NW Europe, which lasted throughout the Late Palaeozoic and the Mesozoic eras. Widespread rifting and magmatism developed north of the foreland of the Variscan Orogen during the latest Carboniferous and continued in some of the areas, like the Oslo Rift, all through the Permian period. We review the geological development of the Oslo Rift through its six stages of development (Ramberg and Larsen, 1978, Sundvoll et al., 1990, Olaussen et al., 1994), focusing on the four first - their lavas, sediments and tectonic structure, and briefly put it into the plate tectonic framework of NW Europe.

\section{The Variscan orogeny, the Tornquist line and the Oslo Rift}

The Oslo Rift sediments exhibit great similarities to the Lower Rotliegendes in the Northern European Permian Basin and in Kattegat and may be regarded as a prolonged northern arm of the Northern Permian Basin. The Skagerrak Graben is the southern part of the Oslo Rift and is the link between the two tectonic systems (Heeremans et al., 2004).

Recent reviews of post-Variscan tectonics in Western Europe (McCann et al., 2006; Ziegler et al., 2006) have described the genetic relations and the timing between the Variscan orogeny and subse-

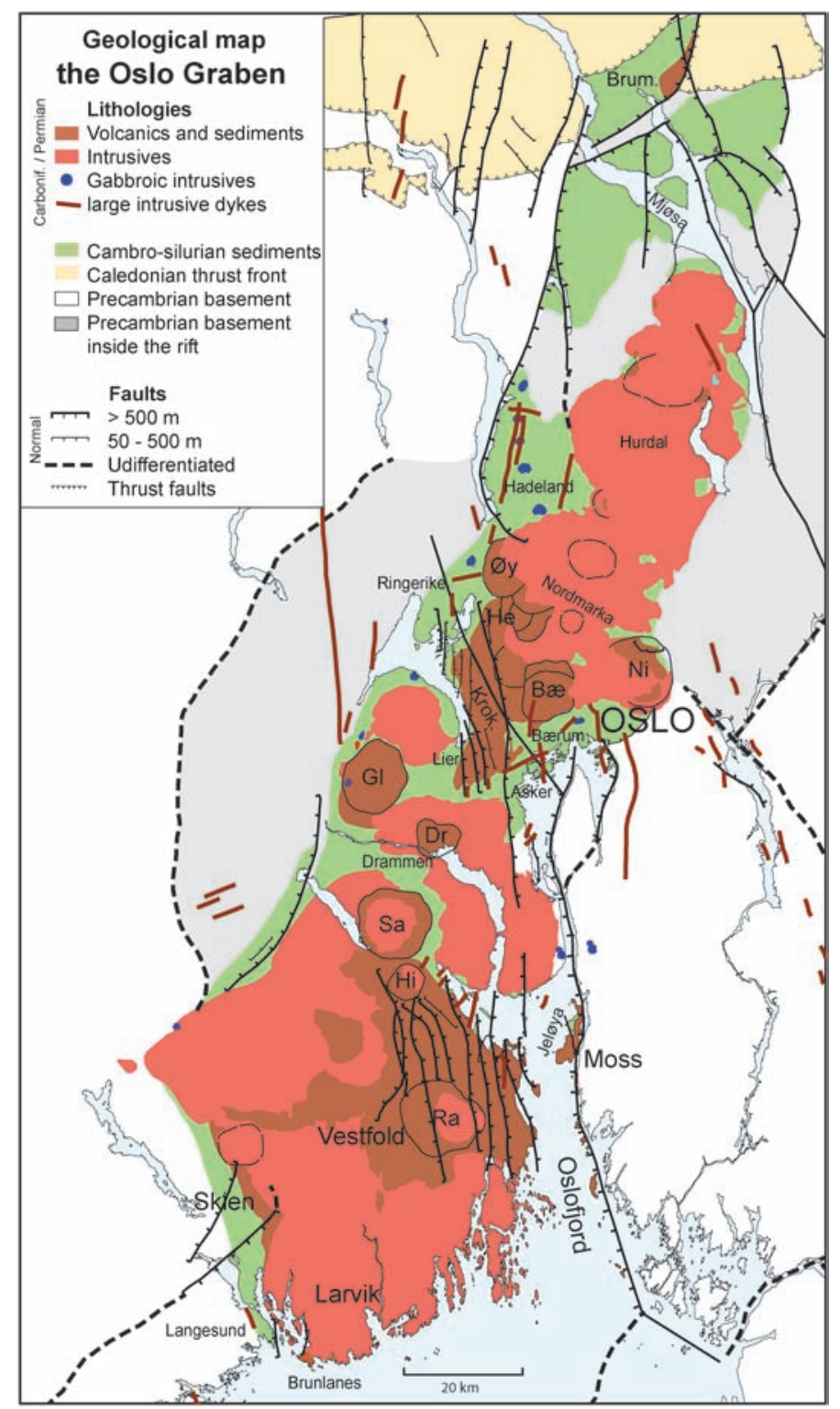

Figure 1 Simplified geological map of the Oslo Graben area. Brown-includes both volcanics, sediments and large dykes related to the Oslo Graben; Carboniferous-Permian age. Red-large Permian batholithic intrusions. Small blue dots-Permian gabbroic intrusions. Green-Lower Palaeozoic sediments. Yellow-the Caledonian thrust front. White-Pre-Cambrian basement rocks. Abbreviations for different areas: Brum. $=$ Brumunddal, Krok. $=$ Krokskogen, and for the caldera volcanoes; $\emptyset y=\emptyset$ yangen, $\mathrm{He}=$ Heggelia, $N i=$ Nittedal, $B a=$ Barum, $G l=$ Glitrevann, $D r=$ Drammen, $\mathrm{Sa}=$ Sande, $\mathrm{Hi}=$ Hillestad and $\mathrm{R} a=$ Ramnes. 


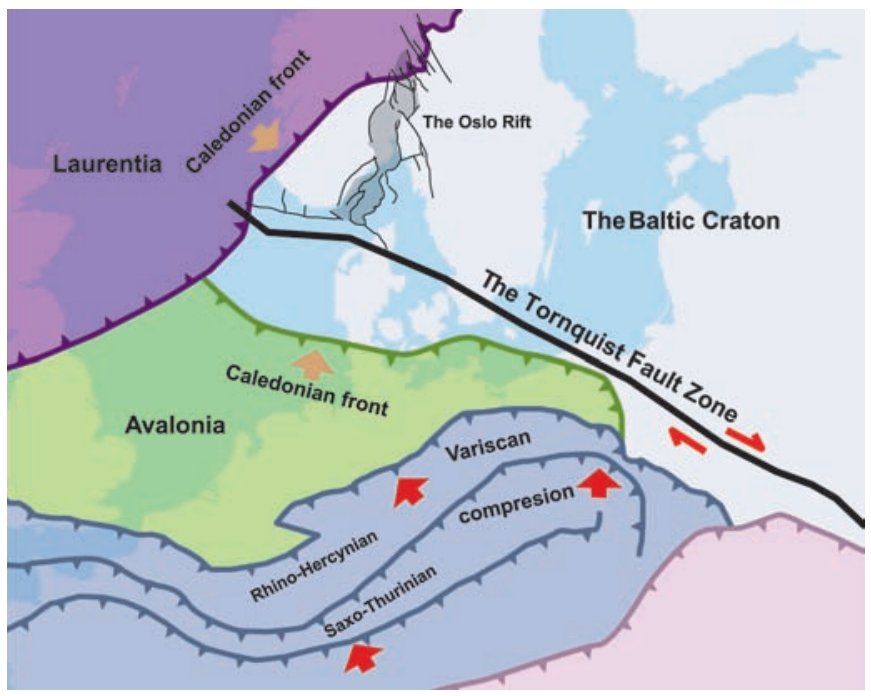

Figure 2 Simplified tectonic overview of West Europe with the Variscan front, the Tornquist fault system and the Oslo Rift. Also shown are the pre-rift configurations with the Caledonian structures and the boundary of the Fennoscandian Craton.

quent large, mostly NW-SE striking, wrench fault systems. The largest and northernmost is the Sorgenfrei-Tornquist Zone (Figure 2) that strikes across Scania (Skåne) into the North Sea (north of the Ringkøping-Fyn High), developing at least partly as a dextral strikeslip fault system. North of this fault, extensional stress fields developed widespread rifting, being linked to the late stages of the orogeny and to the strike-slip faulting (Heeremans et al., 1997). Rifts formed both inside the orogen and in the foreland to the north, even extending into the Fennoscandian Craton. The northernmost and the largest of these structures was the Oslo Rift.

Warr (2000) divided the development of the Variscan orogenic system in NW Europe into four phases, separated both in time and in different areas. The last of the four phases is named the Asturian phase and is generally Westphalian to Early Permian in age. Both Ziegler et al. (2006) and McCann et al. (2006) described it as the consolidation phase of the Variscan Fold belt and gave an age $305 \mathrm{Ma}$ as the critical decline of the Variscan orogeny and the onset of rifting. Latest Carboniferous to earliest Permian was the time for the onset of the Oslo Rift, leading up to its climax of both tectonic and magmatic activity (Sundvoll et al., 1990; Heeremans et al., 1997).

\section{The Oslo Rift architecture and nomenclature}

The architecture of the Oslo Rift is very much like that of other well known rift structures. Most have polarity off-set of grabens along the length of the rift axis, as described e.g. by Rosendahl (1987). The Oslo Graben (Figure 3) was subdivided into two rift segments with opposite subsidence polarity (Ramberg and Larsen, 1978). The Akershus Graben segment has an E-verging master fault (the Randsfjord-Hunnselv Fault) to the north, while the Vestfold Graben segment has a W-verging master fault (the Oslofjord Fault) to the south. These two half grabens have their accommodation zone around the city of Oslo, with a joining fault to the west of Oslo in the Kjaglidalen-Krokkleiva Transfer Fault (Heeremans et al., 1997). Today, we add the third Rendalen Graben segment to the north of the Akershus Graben, also with a west-verging master fault system, the Rendalen Fault (Skjeseth, 1963; Larsen et al., 2006). The accommodation, or transfer system, between the Akershus Graben and the Rendalen Graben is represented by the NE-SW trending Solberg Horst, beside lake Mjøsa.

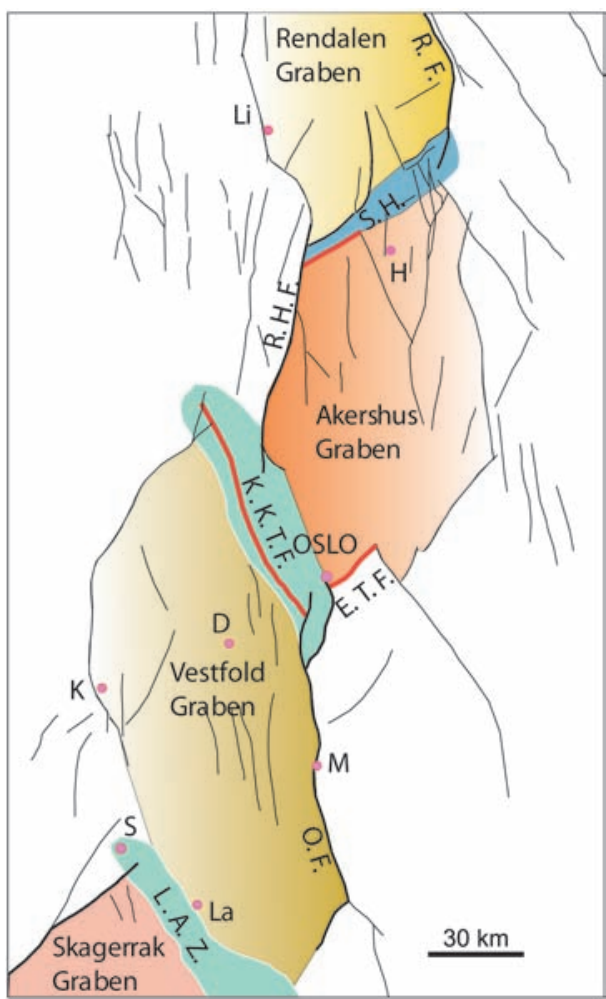

Figure 3 The graben segments and the graben polarity, the master faults, the accommodation structures and the transfer fault in the Oslo Rift. Abbreviations of the structural nomenclature: R.F. = Rendalen fault, S.H. = Solberg Horst, R.H.F = Randsfjorden-Hunnselv Fault, K.K.T.F. = KrokkleivaKjaglidalen Transfer Fault, E.T.F. = Ekeberg. Transfer Fault. O.F. = Oslofjord Fault, and L.A.Z. = Langesund Accommodation Zone. $\mathrm{Li}=$ Lillehammer, $\mathrm{H}=$ Hamar, $\mathrm{D}=$ Drammen, $\mathrm{K}=$ Kongsberg, $M=$ Moss, $S=$ Skien, $L a=$ Larvik.

Finally, the offshore Skagerrak Graben represents the southernmost part of the Oslo Rift, and abuts towards the NW-SE trending Sorgenfrei-Tornquist Zone in the south. The two Akershus and Vestfold graben segments form the classical Oslo Graben which is $220 \mathrm{~km}$ long and about $60 \mathrm{~km}$ wide. Adding the $100 \mathrm{~km}$ long Rendalen Graben in the north, and the $180 \mathrm{~km}$ offshore Skagerrak Graben in the south makes the total length of Oslo Rift about $500 \mathrm{~km}$. The Skagerrak Graben is broader than the other segments to the north, and is composed of several more or less overlapping grabens (Heeremans et al., 2004). The rift axis here strikes NE-SW, perpendicular to the Sorgenfrei-Tornquist fault system.

\section{The petrogenesis of a high volcanicity rift}

Larsen and Sundvoll (1984) summarized the Oslo Graben part of the Oslo Rift as a north-south trending Permo-Carboniferous high-volcanicity continental rift system, much like the recent East African rifts of Kenya and Ethiopia. The high volume of volcanics filling the rift is a feature common to both, and distinguishes them from other continental low-volcanicity rifts such as the Baikal Rift and the Viking Graben. These two categories of rifts are useful descriptive end-members (Barberi et al., 1982).

A thorough analysis of the available data from the Oslo Rift was undertaken by Neumann et al. (2004). They discussed the magma origin and concluded that at least three mantle components have contributed to the petrogenesis of the basaltic magmas, the oldest apparently being derived from an enriched mantle source. This source was most likely located in the lithospheric mantle and might have been metasomatically altered by older carbonatitic fluid-rich 
melts (Anthony et al., 1989). The main mantle source for the basaltic magmatism was a prevalent depleted mantle. It may represent the composition of the base of the local lithospheric mantle, and the asthenosphere beneath, which partly melted in response to localized thinning of the lithosphere due to the extension. Anthony et al. (1989) also suggested an alternative scenario involving a mantle plume, with depleted characteristics, actively up-welling beneath the lithosphere. The most primitive lavas appear to involve low degree partial melting of one or more sublithospheric mantle sources. The rising mantle-derived magmas were modified by shallow-level processes, including magmatic differentiation, general fractional crystallisation, magma mixing and lithospheric contamination that masked the geochemical signature of the mantle source.

Large volumes of mantle-derived basaltic magma formed chambers near the Moho at c. $36 \mathrm{~km}$ depth. This also led to anatectic melting in the Precambrian host-rocks. Initial $\mathrm{Sr}$ isotopic ratios significantly above 0.7039 are typical of the syenitic and granitic rocks and imply influence of crustal contamination in the lower crust (Sundvoll et al., 1990) After $280 \mathrm{Ma}$, the rocks show a clear trend of increasing initial ratios; mantle signature is only present in the larvikites and the rhomb-porphyry and basalt lavas. Sundvoll et al. (1990) interpreted the Sr-initial ratios to reflect the relative importance of mantle- versus crustal-derived melts. At c. 280 and $275 \mathrm{Ma}$, the magmatism became dominated by melts (syenitic and granitic) containing a larger crustal component. The mantle source had slowly become inactive, but mantlederived magmas were still undergoing fractional crystallisation in magma chambers in the lower crust giving rise to evolved rocks such as larvikites and late rhomb porphyry lavas, and to basaltic central volcanoes with shallower crustal magma chambers at c. $20 \mathrm{~km}$ depth. This termination of new mantle material into the Oslo Rift starts the mature stage of the rift. From this time, the slow tectonic and magmatic decay of the Oslo Rift started, and the rift segments developed differently. This long "aftermath" period towards the final termination lasted about 15 million years in the Vestfold Graben, but as long as 35 million years in the Akershus Graben. The transition from the "mantle melting" to the "mature stage" and further to the "aftermath" is also reflected in a change in magma-tectonic style: (a) the magmatism migrated towards the central part of the graben, and (b) fissure eruptions and normal faults gave way to central volcanoes and, finally, to explosive volcanism and calderacollapse. Mantle derived melts appear to have been present somewhat later under the Akershus Graben than under the Vestfold Graben. This is in agreement with the proposed northwards propagation of the rift and its magmatism.

The asthenospheric mantle source of the most primitive magmas bears the signature of being plume-related. The discussion on the influence (if any) of a deep mantle plume on the magmatism in the Oslo Rift has been a controversy for about twenty years. Today, opinions seem to be swinging in favour of a plume, apparently supported by geophysical evidence (Torsvik et al., in press).

\section{The six stages of development}

\section{Stage 1: The proto-rift forerunner to rifting}

The Oslo Rift was initiated in the Late Carboniferous with deposition of a thin carpet of sediments in the southern two-thirds of what later was developed as the Oslo Graben. No record of sedimentary rocks from this forerunner stage are observed NE of the city of Oslo, suggesting non-deposition. These sedimentary rocks are named the Asker Group (Figure 4), which in the central part of the Graben is subdivided into three formations, of which the two first: the Kolsås Formation and the Tanum Formation belong to the protorift stage.

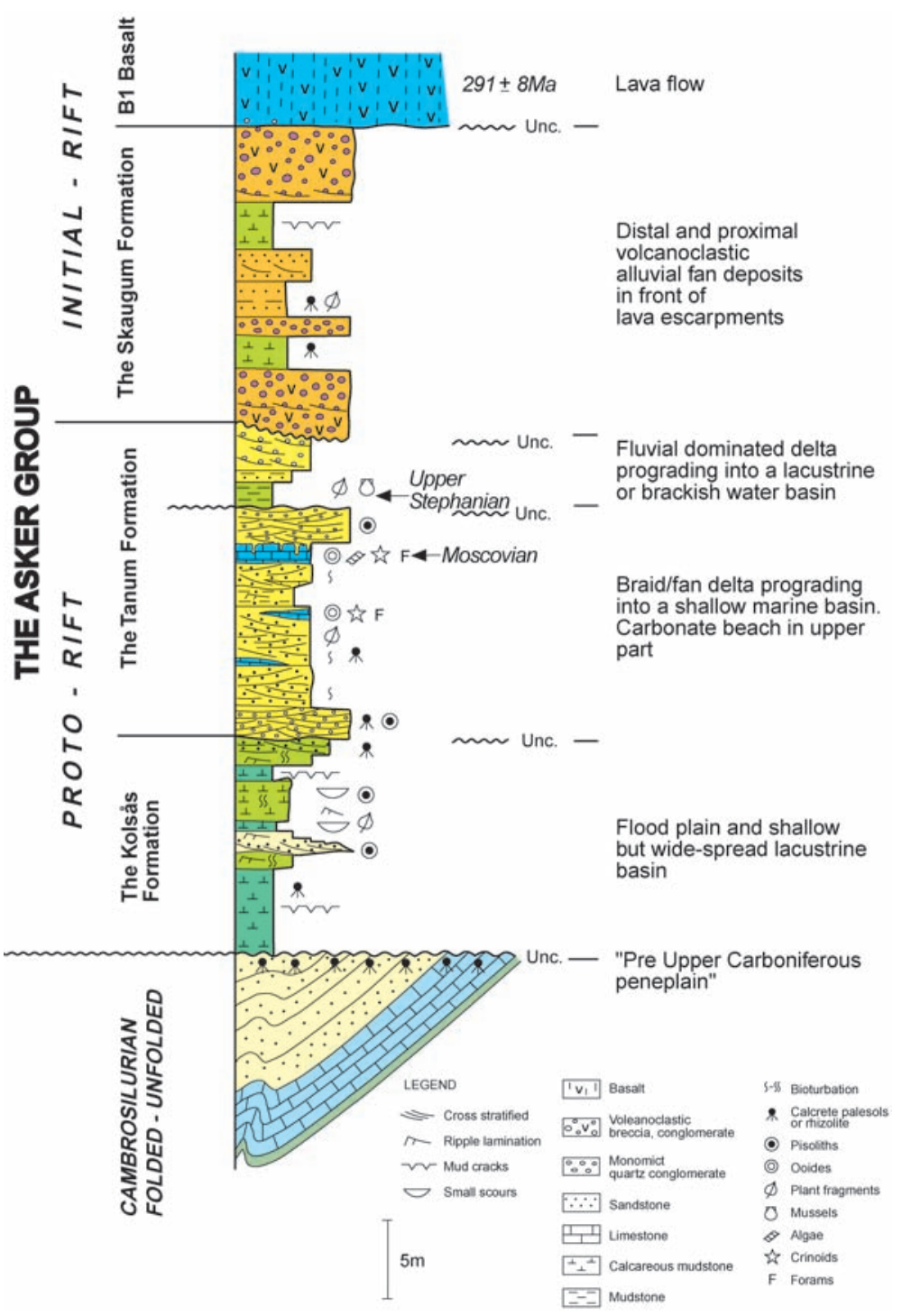

Figure 4 An overview of the stratigraphy of the two first stages of the development in the central part of the Oslo Graben.

In the central part of the Oslo Graben, the up to $20 \mathrm{~m}$ thick Kolsås Formation unconformably overlies the folded Cambro-Silurian sediments. The formation is dominated by red mudstones and sandstones with subordinate greyish to greenish conglomerates, limestones and rare anhydrite. The depositional environments have been interpreted as floodplain, fluvial stream channel fill and shallow lake (Dons and Gyøry, 1967; Henningsmoen, 1978; Olaussen et al., 1994). Immature to mature calcrete soil profiles (paleosols) are recognised in the red overbank and floodplain facies (Olaussen, 1981). This, together with evaporite minerals suggest that arid and semi-arid conditions must have prevailed during the deposition of the Kolsås Formation. A 30 m thick similar unit occurs in the southernmost part of the Vestfold Graben (Olaussen and Dahlgren, 2007).

The overlying $20 \mathrm{~m}$ thick Tanum Formation locally cuts down into the underlying Kolsås Formation. Also in the southern part of the Oslo Graben, an unconformity separates a lower finer grained unit from an upper $60 \mathrm{~m}$ thick coarser section. The Tanum Formation is well known for grey quartz conglomerate beds, which reach up to $5 \mathrm{~m}$ in thickness and are often large-scale cross-stratified and interbedded with medium to very coarse grained or pebbly sandstones. Grey and finer grained sandstones, green and less common red mudstone and limestone are other common lithologies. Dark greyish plant-rich, minor coaly, mudstones have been observed. The Tanum Formation has been interpreted as representing alluvial 
stream channels, floodplains and deltaic deposits (Dons and Gyøry, 1967; Olaussen et al., 1994). The coarser grained units are interpreted as braid plains and fan deltas deposits. Up to two meter thick calcrete profiles with hardpan and some silcretes show evidence of development of mature soil profiles in an arid to semi-arid climate. A thin marine limestone (sandy grainstone) overlies a fluvial or fluviomarine channel in the Kolsås area. This up to $2 \mathrm{~m}$ thick bed (Knabberud Limestone Member) is interpreted as a beach deposit (Figure 4). Clasts of this lithology are also recognised in other central parts of the Oslo Graben. Cross-stratified and horizontally laminated carbonate beds in Skien area resemble the same formation, suggesting a widespread marine incursion in the Oslo Graben (Olaussen, 1981). The scattered occurrence of foraminifers (fusulinids), e.g., Novella evoluta mosquensis (Rauser) in the limestone suggests a late Bashkirian (Westaphalian $\mathrm{A}+\mathrm{B}$ ) to late Moscovian (Westphalian D) age for the marine incursion. The fauna (freshwater mussels, fish and reptile remains) and flora in the uppermost part of the Tanum Formation and the overlying Skaugum Formation in the Asker area was suggested to be correlative with the Lower Permian in Northern Europe (Holtedahl, 1931; Höeg, 1936). It is suggested that this fossil-bearing unit in the Tanum Formation in Asker overlies the Knabberud Limestone Member. Eager (1994) reviewed the freshwater mussels and suggested a correlation with Upper Pennsylvanian in North America. The flora has also been reviewed and indicates a stage between Westphalian/Stephanian to Stephanian in northern Europe. The age of the Tanum Formation is also constrained by the radiometric age $(291 \pm 8 \mathrm{Ma}$, Sundvoll et al. (1990) in the central Oslo Graben) and 300 $1 \mathrm{Ma}$, Corfu and Dahlgren (2007) in the southern Oslo Graben) of the first overlying lava. The formation was deposited prior to the major outpouring of lavas.

The marine Knabbereud Limestone shows an affiliation with carbonate platform units of the same age beneath the Barents Sea, eastern and southern Europe. This implies that the Oslo area could have been flooded in the Late Carboniferous from both the east and the south. The variable lithologies and facies variations observed in the Tanum Formation are consistent with deposition during a period of major climatic and sea level changes, as recorded at the end of the Carboniferous, elsewhere.

Spread over most of the Oslo Region, we find sill intrusions that are radiometrically dated to the Late Carboniferous (308-305 Ma), which indicate a "mid" Pennsylvanian age (Sundvoll et al., 1992; Sundvoll and Larsen, 1994). This corresponds to the "key-age" for the start of magmatic activity, as also suggested by Ziegler et al. (2006). The sill intrusions are primarily of syenitic composition (maenaite), but also basic camptonites occur. The thickness of the sills varies from $\mathrm{cm}$-scale to more than 10 meters.

\section{Stage 2: The initial rift and first basaltic volcanism}

Stage two (Figure 4) exhibits only basaltic lava flows and an up to $20 \mathrm{~m}$ thick volcaniclastic unit, the Skaugum Formation of the Asker Group. The basalts from this stage show the whole suite of compositions from highly silica undersaturated melilitites to oversaturated quartz tholeiites. The different basaltic lavas, however, are found in different areas or provinces during this very early development of the rifting.

In the southernmost province of Brunlanes (Figure 1), a total stratigraphic thickness of $800 \mathrm{~m}$ of basaltic lavas is located. The Brunlanes basalt flows are relatively thin $(\sim 5-0.5 \mathrm{~m})$, and all are silica undersaturated melilitites and nephelinites. Recent U-Pb-dating has given the age $300 \mathrm{Ma}$ for the earliest flows in the south (Corfu and Dahlgren, 2007). We therefore assume that these highly Si-undersaturated basaltic lavas are the oldest in the rift system. These most strongly alkaline and undersaturated basalts erupted in an initial rift setting and are similar to the proto-basalts in the Kenya rift (Williams, 1970 and 1971). In both rifts, they erupted closest to the potential "hot spot" and very early during the rift evolution.

To the northwest of Brunlanes, an equally thick suite of basaltic lavas are exposed in the Skien-Porsgrunn area called the Skien basalts. The flows are slightly thicker than in Brunlanes and vary in composition. These volcanic rocks are Si-undersaturated, mostly basanites in the lower part and more alkaline olivine basalts in the upper half. Thin volcaniclastic sediments and pyroclastic products are found between some of the lava flows. The Skien basalts, and most likely also the Brunlanes basalts, came from an enriched mantle source, potentially as a result of low degree partial melting within the garnet-bearing part of the mantle (Anthony et al., 1989). Thus, the earliest and southermost basalts in the Oslo Rift indicate a low degree of partial melting in an asthenospheric mantle source, subsequently modified by lithospheric mantle and crustal components (Neumann et al., 2004). A possible mantle plume or several smaller plumes have been inferred by Wilson et al. (2004).

The largest basalt province during Stage 2 is in the Vestfold/ Jeløya area, in the central Oslofjord area and continues all the way to northwest of Drammen. The thickness of the Holmestrand/Jeløya basalts varies from $1500 \mathrm{~m}$ at Jeløya, close to the Oslofjord Fault, to about $100 \mathrm{~m}$ at places in central northern Vestfold. The composition of this basalt suite is ordinary alkaline olivine basalts, and the thickness of the individual flows varies from a few meters to c. $10 \mathrm{~m}$. Some few flows of high-Ti basalts are found both at Jeløya and in Vestfold (Schou Jensen and Neumann 1985, Neumann et al., 1989). Many flows are aphyric, but flows with phenocrysts of olivine (mostly altered), augitic clinopyroxene and plagioclase are more common. The basalts erupted from a series of composite fissure volcanoes and from shield volcanoes, mostly as relatively thin compound lava flows, with nice examples of aa-lavas, pahoehoe-lavas and columnar jointing. Volcaniclastic sediments are frequent between the flows; they are mostly thin and varing from fine sand (wind blown) to well-rounded coarse conglomerates. Pyroclastic products are also found, but are not frequent.

North of the basaltic lava field in Vestfold, no alkaline olivine basalts are found north of Drammen. However, in Lier and Asker, we find sediments in this stratigraphic position. Alluvial debris flows were building out towards the north from the large basalt field in Vestfold. The sedimentary structures indicate a northward transport and all clasts are of alkaline olivine basalts. These, up to $30 \mathrm{~m}$ thick, red sediments are named the Skaugum Formation and occur only in the central part of the Oslo rift. The unit is dominated by volcaniclastics, varying from well sorted sandstones to coarse conglomerates. Although there is an abrupt change in composition and in colour from grey to red between the Tanum and Skaugum formations, no major unconformity is observed. Also some of the freshwater fauna and flora seen in the Tanum Formation continue into the Skaugum Formation. Inverse graded breccia occurs and is interpreted as deposition from debris flows. Together with similar continental depositional settings as in the Tanum Formation, this suggests a more proximal facies in the Skaugum Formation, probably representing an alluvial fan deposit (Olaussen et al., 1994). The Skaugum Formation also exhibits calcrete soil profiles, suggesting a semi-arid to arid climate during deposition.

In Lier and Asker, on top of the Skaugum Formation volcaniclastic sediments, there occurs a single aphyric basaltic lava-flow. It covers the whole of the central Oslo area, with a thickness varying from 5 to $20 \mathrm{~m}$, and must have erupted as one simple flow from a fissure volcano. This flow, called the Kolsås basalt, has a quartz tholeiitic composition and is the only basalt in the Oslo Rift of this composition. North of this area, there is no indication of any eruption at this stage in the rift.

\section{Stage 3: The rift climax, with rhomb porphyry fissure volcanoes}

When the change to Stage 3 started, a new era opened (Figure 4), marked by the eruption of rhomb porphyry $(R P)$ lavas. With this climax stage of the Oslo Rift, the volume of eruptions increased. The eruptions of alkaline olivine basalts did not stop, but continued into Stage 3. It continued and spread further to the north, but most likely decreased in volume and intensity. The earliest rhomb porphyry lavas had extremely large volumes. Together they covered an area of 
the southern and central Oslo Graben from well north of Oslo city and to the outer part of the Oslofjord, i.e. about $10,000 \mathrm{~km}^{2}$. With an estimated thickness of at least $100 \mathrm{~m}$, the total volume may have been as large as $1,000 \mathrm{~km}^{3}$. But most subsequent RP-flows were much smaller than this first flow, varying in thickness from about 5 $\mathrm{m}$ to more than $100 \mathrm{~m}$. Rhomb porphyry lavas are found all over the classical Oslo Graben, from Brumunddal in the north to Brunlanes in the south, a distance of about $220 \mathrm{~km}$. They are today concentrated in two large and a number of smaller lava plateau areas. The two large provinces are the Krokskogen lava plateau (about $400 \mathrm{~km}^{2}$ ) west of the city of Oslo and the Vestfold lava plateau $\left(>1,000 \mathrm{~km}^{2}\right)$ in northern and central Vestfold. The stratigraphical thickness of the lavas in Vestfold is about $3 \mathrm{~km}$, and about $75 \%$ are rhomb porphyries. At Krokskogen, the thickness is about $900 \mathrm{~m}$ with about $80 \%$ rhomb porphyries.

The production rate of RP-flows in the different areas varied. In Vestfold, about 50 flows erupted during about 10 million years giving a production rate of about one flow every 250,000 years. At Krokskogen, 20 flows erupted over 14 million years giving a production rate of about one flow every 600,000 years (Sundvoll et al., 1990). The eruptions continued longer at Krokskogen than in Vestfold. And the first of the four flows in Brumunddal, in the southern part of the Rendalen Graben in the north, is much later than the first RP-flows further south.

The rhomb porphyries have an intermediate composition with c. $55 \% \mathrm{SiO}_{2}$ and with relatively high content of $\mathrm{Na}$ and $\mathrm{K}$. Feldspar phenocrysts constitute from c. 5 to $30 \%$ of the volume, and the feldspar crystals are mostly larger than $1 \mathrm{~cm}$. The phenocryst feldspar is a ternary feldspar, zoned with a Ca-rich core and K-rich rim (Harnik, 1969). Such lavas, with a high content of Si and phenocrysts, would be expected to have a relatively high viscosity (Sæther, 1962). But the volcanological "performance" of the RPlavas indicates that they flowed out quietly over large areas in "Hawaiian" style, accompanied by hardly any pyroclastic products. Consequently, the viscosity must have been relatively low. Two factors likely explain this behaviour. Firstly, the temperature must have been relatively high, being calculated to about $1050-1100^{\circ} \mathrm{C}$ (Larsen, 1978), i.e. about the same temperature as that of an evolved basalt with plagioclase phenocrysts. Secondly, there must have been a high content of dissolved gases. Dissolved water and other gases like halogens will decrease the viscosity. Recent analysis has shown that the content of $\mathrm{Cl}$ is low in the RP-lavas, but the content of $\mathrm{F}$ is very high, 0.25 to $0.5 \%$. Calculations using USGS software "Conflow" (Mastin and Ghiorso, 2000) give viscosities of between 3 and $5 \mathrm{~Pa} \cdot \mathrm{s}$ in the southern part in the southern part using temperatures between 1050 and $1100^{\circ} \mathrm{C}$, gas-dissolution of $1-3 \%$ and phenocryst content between 3 and $10 \%$. This is only slightly more viscous than "Kilauea basalt" from Hawaii and explains the rhomb porphyry lavas volcanological behaviour.

Outside the lava plateau, large, mostly N-S striking RP-dykes occur over most of the area. Our impression is that the rare and huge RP lava flows erupted from large fissure dykes; the RP lavas are therefore classified as monogenetic fissure eruptions. Most of the RP-lavas have the appearance of simple flows; not compound flows like most of the basalts. By contrast, the basalts in Stage 2 probably erupted from polygenetic fissure and central volcanoes as compound and thin flow systems. Both at Krokskogen and in Vestfold, we find basalts interfingering with the RP-lavas. The basalts are mostly alkali olivine basalts, but also undersaturated basanites occur.

Apart from the extrusions, some sedimentary units are preserved as remnants of the original basin fill within the Oslo Graben (Olaussen et al., 1994). They can be grouped into two types: sedimentary rocks preserved between the lava flows, and thick (up to $1 \mathrm{~km}$ ) units above the lava flows. The first group include fluvial and alluvial fan deposits and thin calcrete paleosols. Units with finer grained ripple-laminated sandstones and mudstones with stromatolithic limestone provide evidence for the development of ponds or smaller lakes. Up to $1 \mathrm{~m}$ thick, well sorted and rounded, large scale cross-stratified fine grained sandstones are interpreted as eolian dunes. A 400 m thick canyon-fill in the Krokskogen lava plateau, presumably terminated in an alluvial fan on the lowlands in the west. This, the Migartjern conglomerate, is uncomformably overlain by younger basalt and rhomb porphyry lavas (Larsen, 1978). In the second group, two major units are recognised: a minimum $1 \mathrm{~km}$ thick, coarse rhomb porphyry conglomerate (Brøgger, 1900; Størmer, 1935; Larsen et al., 1978), banked against the eastern master fault in the Vestfold Graben, and a $800 \mathrm{~m}$ thick dune and wadi deposit in the southern part of the Rendalen Graben in Brumunddal. The first of these represents debris flows, stream and sheet floods in an alluvial fan setting. The second, comprising the down-faulted red and yellow Brumund Formation, has both large scale, cross-stratified eolian dune deposits and fluvial stream channel and flood plain deposits (Rosendahl, 1929). Recent mapping and sedimentological studies of the Brumund Formation have also recognised lacustrine limestones and calcrete paleosols (Lothe et al., 1999). These authors recorded bedding to dip south-eastwards up to $60^{\circ}$, and to decrease upwards, and interpreted a syn-rift depositional environment. The sedimentary rocks which are preserved in the hanging-wall towards master faults are a response to increasing topography in the graben. These sedimentary rock units are compared with the Rotliegendes deposits in the North Permian Basin.

The end of the climactic Stage 3 was marked by the emplacement of major larvikitic batholiths.

\section{Stage 4: The mature rift, with central volcanoes and caldera collapse}

The volcanic processes and the products again changed when the rift-development approached Stage 4. Basaltic central volcanoes started to develop in many parts of the rift, which was now developed as a prominent structure with large faults bounding the grabens. Rhomb porphyries continued to erupt during this stage, but most likely with a decreased intensity and volume, together with the new formation of central volcanoes.

At tectonically strategic places all along the Oslo Graben, central volcanoes started to form. Most were basaltic with slight variation in composition. They were mainly alkaline olivine basalts, but also more Si-saturated transitional types occur as in the Glitrevann volcano, north of Drammen. The most prominent tectonic setting of some of these extrusions is a N-S trending string of volcanoes along the central axis of the Vestfold Graben, from Ramnes in the south to Glitrevann, NW of Drammen (Ramberg and Larsen, 1978). All central volcanoes did not necessarily start to form at the same time and it is possible that the southern ones started before those in the north.

The diameter of the calderas at the present erosion level varies between $12 \mathrm{~km}$ (e.g., at Ramnes and Nittedal) and $6 \mathrm{~km}$ (e.g., at Drammen). We infer from comparisons elsewhere that the original diameter of the pre-caldera volcanoes at their base was about three times the size, i.e. 36 to $18 \mathrm{~km}$. Central volcanoes of similar setting with calderas are found in the Kenya Rift Valley e.g. the Silali, Suzwa and Menengai volcanoes (Williams, 1970; Baker et al., 1971). By analogy with the East African Rift, the heights of the central volcanoes in the Oslo Rift are estimated to have been in the order of $1-1.5 \mathrm{~km}$ above the rift valley floor. Apparently, the Kenya and the Ethiopian rifts are today in a situation similar to that in the Oslo Rift in the middle of Stage 4. The rift valley had formed, the central volcanoes were active and several of them had reached a mature explosive caldera-forming stage.

All the large central volcanoes inside the Oslo Rift seemed to have matured petrologically. Olivine, augitic clinopyroxene and plagioclase crystallized out of the basaltic magma leaving a felsic, mildly alkaline magma as the residual melt product. The latter was mostly trachytic in composition, but some also developed to alkaline rhyolites. The magma-products finally erupted explosively during the caldera formation. At the present erosion level in the Oslo Graben, felsic ring-dykes and central domes are exposed together with large and small remnants of ignimbritic effusives mixed together with basalts and other pre-caldera products. Only in Vestfold do we find thick and widespread ignimbrites in the upper part of 
the rhomb porphyry succession outside the calderas, most likely erupted from the nearest calderas. The age of these trachytic ignimbrites (T1 and T2) in inner Vestfold has been dated to $288 \mathrm{Ma}$ and $285 \mathrm{Ma}$, respectively (Sundvoll and Larsen 1990). Even though these datings have limited precision, they indicate that the explosive eruptions in Vestfold are older than the ones further north, and that the different development stages distinguished in the Oslo Graben, were not synchronous, but started in the south. At Krokskogen, we lack significant dating among the caldera-related extrusive products, but the intrusions (ring-dykes and central intrusions) in the caldera cluster formed at c. $270 \mathrm{Ma}$, implying that the explosions from these calderas (e.g., the Øyangen caldera) most likely were significantly younger than in Vestfold. Since ignimbrites have not been observed in any part of the Krokskogen plateau, and the uppermost RP-lava was dated to c. $276 \mathrm{Ma}$, we have an interval of about 10 Ma between the first Vestfold caldera explosions and those at Krokskogen.

The youngest sedimentary units preserved inside the Oslo Rift calderas are red breccias, sandstones and thin laminated mudstones, often associated with pyroclastic rocks. These units are interpreted to be of alluvial and lacustrine origin, and the best preserved are inside the Nittedal caldera (Naterstad, 1978).

Small alkaline gabbros were intruded during Stage 4 at c. 265 $\mathrm{Ma}$ and are located along N-S tectonic lineaments like at Hadeland, and in clusters as in the central Oslofjord area (Neumann et al., 1985). They are only from $1 \mathrm{~km}$ to $100 \mathrm{~m}$ in diameter, sometimes exhibit layering and represent basaltic magma chambers that existed below smaller basalt volcanoes at the same time as the larger ones that developed to caldera volcanoes (Steinlein, 1981).

The large batholithic Drammen granite and a slightly smaller body further to the north, the Finnemarka granite, intruded into the northern part of the Vestfold Graben, slightly south of the transfer system that separates the latter from the Akershus Graben.

\section{Stage 5: The magmatic aftermath, with major syenitic batholiths.}

After the youngest intrusions related to the development of the Stage 4 calderas (c. $266 \mathrm{Ma}$, Sundvoll and Larsen, 1990), a set of large batholiths developed mostly in two areas - in inner Vestfold (west of the lava areas and north of the older larvikite batholiths) and in the Nordmarka and Hurdal areas, north of Oslo (Figure 1). Probably due to the present erosional level, no extrusions or sediments can be linked to this Stage 5 of igneous activity, which lasted from c. 265 to $255 \mathrm{Ma}$. These batholiths are mostly alkali syenitic to alkali granitic in composition and are called Nordmarkites and Ekerites. Several are intruded into the lava plateau, calderas and earlier batholiths, and partly destroyed these structures.

\section{Stage 6: Rift termination, with the youngest small granite intrusions}

This last stage of magmatic activity occurred in two separate areas, both north of the city of Oslo: in the Tryvann area in the northern hills of Oslo, and further to the north in Hurdal. The intrusions are granitic in composition with ages from 250 to $245 \mathrm{Ma}$ (Sundvoll et al., 1990). Younger dikes also exist, primarily in the northern Oslo Graben (Torsvik et al., 1998, Heeremans et al., 2000).

\section{Epilogue}

The geological development of the high-volcanicity continental Oslo Rift is described through six stages in Late Carboniferous and all through the Permian. Such palaeorifts structures are rarely exposed due to post-rift cooling, subsidence and younger sedimentation. Though the Oslo Rift has been studied for nearly 200 years and has the easiest possible access, with the capital, Oslo, located in the middle of the structure, many questions remain unresolved, awaiting new investigations.

\section{References}

Anthony, E.Y., Segalstad, T.V., and Neumann, E.-R., 1989, An unusual mantle source region for nephelinites from the Oslo Rift, Norway: Geochim. et Cosmochim. Acta, 53, 1067-1076.

Baker, B.H., Williams, L.A.J., Miller, J.A., and Fitch, F.J., 1971, Sequence and geochronology of the Kenya rift volcanics: Tectonophysics, 11, $191-215$.

Barberi, F., Santacroce, R., and Varet, J., 1982. Chemical aspects of rift magmatism, in G. Palmason ed., Continental and oceanic rifts: American Geophysical Union, 223-258.

Brøgger, W.C., 1900, Konglomerater i Kristianiafeltet. I. Om porfyrkonglomeratet paa ørekken Revlingen-Søstrene, en sedimentær formation fra Kristaniafeltet: Nyt Mag. Naturv, 38, 29-64.

Corfu, F. and Dahlgren, S., 2007, Pervoskite U-Pb ages and the Pb isotopic composition of alkaline volcanism initiating the Permo-Carboniferous Oslo Rift: Earth Planet. Sci. Lett. 265, 256-269.

Dons, J.A., and Györy, E., 1967, Permian sediments, lavas and faults in the Kolsås area W of Oslo: Norsk Geol. Tidsskr. 47, 57-77.

Eager, R.M.C., 1994, Non-marine bivalve assemblage in the Asker Group, Oslo Graben and its correlation with late Pennsylvanian assemblages from North America: Jour. Geol Soc., London, 252, 669-680.

Harnik, A.B., 1969, Strukturelle Zustände in den Anothoklasen der Rhombenporphyre des Oslogebietes: Schweizerische Min. Petr. Mitt. 49, 509-567.

Heeremans, M., Larsen, B.T., and Stel, H., 1997, Paleostress reconstruction from kinematic indicators in the Oslo Graben, southern Norway: new constraints on the mode of rifting: Tectonophysics, 266, 55-79.

Heeremans, M., Kirstein, L., Larsen, B.T., and Timmerman, M., 2000, The structural evolution of Permo-Carboniferous dykes and sills in NW Europe: a multidisciplinary approach: Geoscience 2000 Abstracts, p66.

Heeremans, M., Faleide, J.I., and Larsen B.T., 2004, Late Carboniferous-Permian of NW Europe: an introduction to a new regional map, in PermoCarboniferous magmatism and Rifting in Europe: Geol. Soc. London, Spec. Publ. 223, 75-88.

Henningsmoen, G., 1978, Sedimentary rocks associated with the lava series, in J.A. Dons and B.T. Larsen eds, The Oslo Paleorift: Norges Geol. Unders. 337, 17-24.

Holtedahl, O., 1931, Jungpaläozoische Fossilen im Oslogebiete: Norsk Geol Tidsskr. 12, 323-340.

Höeg, O.A., 1936. The Lower Permian flora of the Oslo region: Norsk Geol. Tidsskr. 16, 1-43.

Larsen, B.T., 1978. Krokskogen lava area, in J.A. Dons and B.T. Larsen (Eds.) A review and guide to excursions: Norges Geol. Unders., Bull. 337, 143-162.

Larsen, B.T., Ramberg, I.B. and Schou Jensen, E., 1978. Excursion 3 Central part of the Osloford, in J.A. Dons and B.T. Larsen eds, A review and guide to excursions: Norges Geol. Unders., Bull. 337, 105-124.

Larsen, B.T. and Sundvoll, B., 1984. The Oslo Graben: A Passive High Volcanicity Continental Rift: EOS 65, no 45, 1084.

Larsen, B.T., Olaussen, S., Sundvoll, B. and Heeremans, M., 2006. (English edition 2008). Vulkaner, forkastninger og ørkenklima, in I.B. Ramberg, I. Bryhni og A. Nøttvedt eds, Landet blir til: Norsk Geologisk Forening. p. 284-327.

Lothe, A. E., Haugen, M., Gabrielsen, R., Larsen, B.T., Olaussen, S. and Talbot, M., 1999. Structural and sedimentological aspects of the Early Permian. Brumunddal Sandstone, northern Oslo Graben (abstract, Geol. soc, Norway): Geonytt. p. 68.

Mastin, L.G. and Ghiorso, M.S., 2000, A Numerical Program for SteadyState Flow of Magma-Gas Mixtures through vertical erupive conduits: USGS Open-File Report 00-209. 61 pp (http://vulcan.wr.usgs.gov/Projects/Mastin/Publications/OFR00-209/conflow.htm).

McCann, T., Pascal, C., Timmermann, M.J., Krzywiec, P., López-Gómez, J., Wetzel, A., Krawczyk, C.M., Rieke, H. and LaMarche, J., 2006, PostVariscan (end Carboniferous-Early Permian) basin evolution in Western abd Central Europe, in D.G. Gee and R.A. Stephensson eds, European Lithosphere Dynamics: Geol. Soc. London, Memoir 32, 355-388.

Naterstad, J., 1978, The Nittedal Cauldron (Alnsjøen Area), in J.A. Dons and B.T. Larsen eds, A review and guide to excursions: Norges Geol. Unders. Bull. 337, 99-103.

Neumann, E.-R., Larsen, B.T. and Sundvoll, B., 1985, Compositional variations among gabbroic intrusions in the Oslo Rift: Lithos, 18, 35-59.

Neumann, E.-R., Wilson, M., Heeremans, M., Spencer, E.A., Obst, K., Timmerman, M.J. and Kirstein, L., 2004, Carboniferous-Permian rifting and magmatuism in southern Scandinavia, the North Sea and northern Germany: a review, in Permo-Carboniferous magmatism and Rifting in Europe: Geol. Soc. London, Spec. Publ. 223, 11-40. 
Olaussen, S., 1981, Marine incursion in Upper Paleozoic sedimentary rocks of the Oslo Region, Southern Norway: Geol. Mag., 118, 381-388.

Olaussen, S., Larsen, B.T. and Steel, R., 1994, The Upper Carboniferous-Permian Oslo rift; Basin fill in relation to tectonic development, in Embry, A.F., Beauchamp, B. and Glass, D.J. eds, Pangea, Global environments and resources: Can. Soc. Petrol Geol. Memoir 17, 175-198.

Olaussen, S. and Dahlgren, S., 2007, Environmental setting of the southernmost outcrop of the Carboniferous in the Oslo Rift. An arid syn-tectonic lacustrine and alluvial deposit with possible marine incursions, in Nakrem, H.A.(ed), Vinterkonferansen 2007: Abtracts and Proceedings of the Geological Society of Norway. No 1, 2007, 70-71.

Ramberg, I.B. and Larsen, B.T., 1978, Tectonomagmatic evolution, in J.A. Dons and B.T. Larsen, eds, The Oslo Paleorift: Norges Geol. Unders. 337, 55-73.

Ramberg, I.B. and Spjeldnæs. N., 1978, The tectonic history of the Oslo Region, in E-R. Neumann and Ramberg, eds, Tectonics and Geophysics of Continental Rifts: Reidel Dordrecht, 167-194.

Rosendahl, B.R., 1987, Architecture of continental rifts with special reference to East Africa: Annual Review, Earth and Planetary Science Letters, 5, 445-503.

Rosendahl, H., 1929, The porphyry-sandstone sequence in Brummundal: Norsk Geol. Tidsskr. 10, 367-438.

Schou Jensen, E. and Neumann, E.-R., 1988, Volcanic rocks at Jeløya, central Oslo Region: the mafic lavas: Norsk Geol. Tidsskr. 68, 289-308.

Skjeseth, S., 1963, Contribution to geology of the Mjøsa District and the classical Sparagmite area in southern Norway: Norges Geol. Unders. 220. 226 pp.

Steinlein, O., 1981, En petrologisk og geokjemisk unders $\varnothing$ kelse av lagdelte, gabbroide vulkanplugger i Hurum, Oslo-graben. Univ. i Oslo, cand. Real. thesis, $93 \mathrm{pp}$.

Størmer, L., 1935, Contribution to the geology of the southern part of the Oslofjord: The rhomb porphyry conglomerate with remarks on younger tectonics: Norsk Geol. Tidskr. 15. 43-133.

Sundvoll, B., Neumann, E.-R., Larsen, B.T. and Tuen, E., 1990, Age relations among Oslo Rift magmatic rocks: implications for tectonic and magmatic modelling. Tectonophysics 178, 67-87.

Sundvoll, B., Larsen, B.T. and Wandås, B., 1992, Early magmatic phase in the Oslo Rift and its related stress regime, Tectonophysics, 208, 37-54.

Sundvoll, B. and Larsen, B.T., 1993, Rb-Sr and Sm-Nd relationship in dyke and sill intrusions in the Oslo Rift and related areas: Norges Geol. Unders. Bull. 425, 23-40.

Sundvoll, B. and Larsen, B.T., 1994, Architecture and early evolution of the Oslo Rift: Tectonophysics. 240, 173-189.

Sæther, E., 1962, Studies of igneous rock complex of the Oslo Region, XVIII, General investigation of the igneous rocks in the area north of Oslo. Skrifter Norske Videnskaps Akademi I Oslo, Matematisknaturvitenskapelig klasse: Ny serie. No. 1, 184pp.

Torsvik, T.H., Eide, E.A., Meert J.G., Smethurst, M.A., and Walderhaug, H.J., 1998, The Oslo Rift: New Palaeomagnetic an ${ }^{40} \mathrm{Ar} /{ }^{39} \mathrm{Ar}$ age constraints: J. Geophys. Int. 135, 1045-1059.

Torsvik, T.H., Smethurst, M.A., Bruke, K. and Steinberger, B., 2007, Long term stability in Deep Mantle structure: Evidence from the $\sim 300 \mathrm{Ma}$ Skagerrak-Centred Large Igneous Province (the SCLIP): Earth Planet. Sci. Lett. (submitted).

Warr, L.N., 2000, The Variscan Orogeny: The welding of Pangea, in Woodcock, N. and Strachan, R. eds, Geological History of Britain and Ireland: Blackwell, Oxford, 271-391.

Williams, L.A.J., 1970, The volcanics of the Gregory Rift Valley, East Africa: Bull. Volcanologique, 3, 439-465.

Williams, L.A.J., 1971, The Kenya Rift volcanics: A note on volume and chemical composition: Tectonophysics, 15, 83-96.

Wilson, M., Neumann, E.-R., Davis, G.R., Timmerman, M.J. Heeremans, M., and Larsen B.T., 2004, Permo-Carboniferous magmatism and rifting in Europe: introduction, in Permo-Carboniferous magmatism and Rifting in Europe: Geol. Soc. London, Spec. Publ. 223. 1-10.

Ziegler, P.A., Schumacher, M.E., Dèzes, P., Van Wees, J.-D., and Cloething, S., 2006, Post-Variscan evolution of the lithosphere in the area of the European Cenozoic Rift System, in Gee, D.G. and Stephenson, R.A. eds, European Lithosphere Dynamics: Geol. Soc. London, Memoir 32, 97-112.
Bjørn T. Larsen is educated from the Universities of Bergen and Oslo, with a cand. real. graduation in Oslo in 1979. He has worked at the University of Oslo with the Oslo Graben studies until he in 1986 started working for the Norwegian oil companies. He worked for Statoil, Hydro and Saga with Norwegian and international exploration until 2000 when he started as a consultant. He has continued working in the Oslo Graben together with co-workers from University of Oslo and the Geological Survey of Norway (NGU) parallel with his oilindustry affiliations, and has arranged several professional field trips in the Oslo Graben.

Snorre Olaussen is educated from the Universities of Oslo and Bergen and graduated with his MSc in 1979 and his Ph.D. in 1984. He joined the Norwegian oil industry in 1980, and has worked for Statoil, Saga and Hydro; as a chief geologist in Saga and Hydro. Since 2000 he has been working as a new venture/regional team leader for Eni Norge. He has continued his arrangements in the Oslo Region and has arranged several professional field-trips.

Bjørn Sundvoll is educated from the University of Oslo and received his cand.real. thesis in isotope chemistry. Since 1974, he worked for the Geological Survey of Norway with the working address at the Geological Museum at University of Oslo. He was part of the team that established the isotope laboratory in Oslo. In 1995, he defended his Dr. Philos. thesis on isotope chemistry and radiometric datings of Oslo Graben rocks.

Michel Heeremans is a university lecturer in petroleum geology at the University of Oslo. His interest in the Oslo Graben started during his PhD at the Vrije University, Amsterdam. After his graduation in 1997, he moved to Norway where he continued his work, but now focusing on the Carboniferous-Permian development of NW Europe. His current work focuses mostly on education and database support.
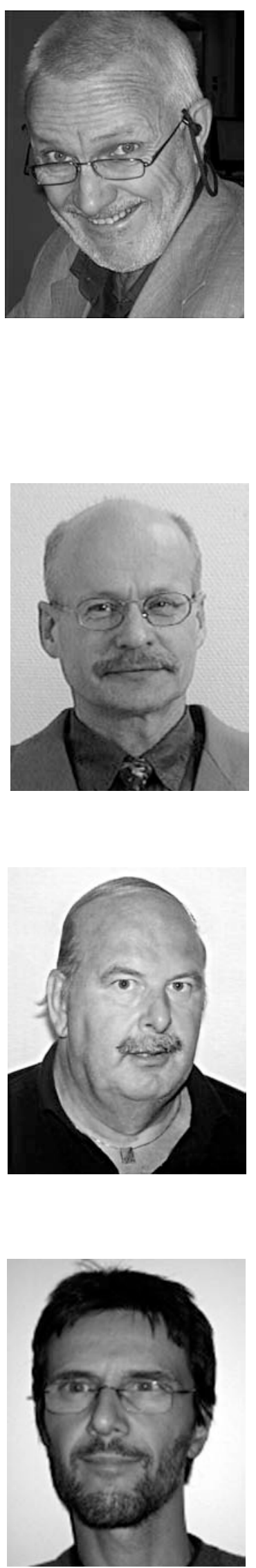